\title{
NEW CORPORATE CONCEPTS UNDER THE 1954 REVENUE CODE
}

\section{Stephen T. Dean $\dagger$ and John F. Headly $\ddagger$}

Within less than six months after enactment of the Internal Revenue Code of 1954, on August 16, 1954, untold man-hours have been expended in a bombardment of the spoken word at tax forums in every section of the country and at every professional and business level. Tons of paper have carried the war of the written word to all but the illiterate. New books, new services, new periodicals, and even a new group of experts have emerged. This avalanche leaves one wondering what more can be added in the midst of such a storm of competing: commentary.

During the period of congressional enactment, the vortex of the storm was the corporate phase included within what is now known as Subchapter C. The many suggestions sought and given by taxpayers' representatives, reflected in 2,916 pages of hearings before the House Committee on Ways and Means, ${ }^{1}$ were substantially disregarded by the Treasury Department and by Congress. New and strange concepts were the order of the day in H. R. $8300^{2}$ as passed by the House of Representatives on March 9, 1954.

The protests of legal, accounting and other professional organizations were recorded in 2,443 pages of hearings before the Senate Committee on Finance. ${ }^{3}$ Thereafter huge segments of the House bill were ripped out and replaced by prior law-with amendments. Other segments of the House bill weathered the storm-but also with amendments.

It is a tribute to those who created and criticized that the final result is a meritorious one. But neither Subchapter C, nor the 1954 Code generally, will be remembered for its simplicity and clarity. Future litigation (the "field day for lawyers" as so aptly described by the

$\dagger$ B.S. 1934, LL.B., 1937, University of Pennsylvania; Member of New York and Philadelphia Bars.

$\$$ A.B. 1924, Haverford College; LL.B. 1927, University of Pennsylvania; Member of Philadelphia Bar.

1. Hearings before House Committee on Ways and Means on H.R. 8300, 83d Cong., 2d Sess. (1954).

2. H.R. Rep. No. 1337, 83d Cong., 2d Sess. (1954).

3. Hearings before Senate Committee on Finance on H.R. $8300,83 \mathrm{~d}$ Cong. $2 \mathrm{~d}$ Sess. (1954). 
President) may eventually provide clarification, but, pending that millennium, there must inevitably be much ambiguity and confusion.

The new approaches reflected in Subchapter $C$ are born of necessity-the positive need for remedial legislation and the negative need to prevent tax avoidance through loopholes available only to the few. For the most part, these approaches have been long considered and recommended by the American Law Institute ${ }^{4}$ and the tax bar generally.

\section{Corporate Organizations}

Section 351 of the 1954 Revenue Code has omitted that part of its predecessor Section 112 (b) $(5)^{5}$ which provided that, in the event two or more persons transferred property in exchange for stock and securities of a controlled corporation, such exchange would be tax-free "only if the amount of the stock and securities received by each is substantially in proportion to his interest in the property prior to the exchange." This meant that each contributing shareholder was required to receive only that number of shares as were "substantially in proportion" to the fair market value of the property contributed. There had been conflict in court decisions, some using what has become known as the "control test," which compares the proportionate interest of each transferor in the property transferred with his proportionate interest in the stock exchanged therefor, ${ }^{6}$ and others using the "relative value test," which compares the gain or loss sustained by each transferor as the result of a non-proportionate contribution. ${ }^{7}$ But the elimination of this conflict does not solve all of the problems. The committee report warns ${ }^{8}$ that a contributor receiving stock in excess of his proportionate share may be taxed on that excess "in accordance with its true nature" - perhaps as a gift or as compensation.

The law now establishes, for the first time, definite rules for the tax treatment of contributions to corporate capital by persons who are

4. Ali Fed. Income Tax Stat. (Feb. 1954 Draft).

5. Int. Rev. Code of 1939. These are the so-called "tax-free incorporation" provisions which require the non-recognition of gain or loss where property is transferred to a corporation in exchange for its stock or securities, provided that, thereafter, the transferors have $80 \%$ control of the transferee corporation as defined in $\S 368(\mathrm{c})$. The revision incorporated into $\$ 351$ follows the recommendation of ALI Fed. Income TAX Stat. $\$$ X600, comments, at 304 (Feb. 1954 Draft).

6. Mather \& Co. v. Commissioner, 171 F.2d 865 (3d Cir.), cert. denied, 337 U.S. 907 (1949).

7. Union Carbon Co. v. Commissioner, 90 F.2d 43 (4th Cir. 1937).

8. Sen. Rep. No. 1622, 83d Cong., 2d Sess. 264-65 (1954), stating: "In any case in which the stock and securities received are not in proportion, the transaction will be treated as if the stock and securities had first been received in proportion and then some of such stock and securities had been used to make gifts, to pay compensation, or to satisfy obligations of any kind." 
not shareholders. ${ }^{9}$ In Brown Shoe Co. v. Commissioner, ${ }^{10}$ it was held that the price of property purchased with tax-free cash received as a contribution from non-shareholders was its cost basis for depreciation and invested capital purposes. Under that decision, the fair market value of property donated by a non-shareholder would also create additional cost basis even though the donation involved no "tax cost" to the corporation. Section 118 now confirms the prior administrative rule that a contribution to capital is not to be included in gross income; ${ }^{11}$ but the new Section 362(c) negates the Brown Shoe decision by providing that property so contributed has a basis of zero; and a cash contribution by a non-shareholder will cause an equivalent reduction in the cost basis of any property acquired with such cash during the 12 months following the contribution, and any balance of cash not expended within 12 months will serve to reduce "the basis of any other property held by the taxpayer."

\section{CORPORATE Distributions}

The field of corporate distributions has been the subject of major revision, although the general pattern of the old law is still discernible. Under Sections 301 and $316^{12}$ the normal corporate distribution (not involving a surrender of stock) generally will be taxed as under prior law: as a dividend to the extent of corporate earnings; ${ }^{13}$ and, to the extent that the distribution exceeds corporate earnings, as a tax-free return of cost basis, with any portion in excess of cost, as capital gain. However, an important change is that if a corporation receives a dividend in property, such corporate distributee must include in its income the lesser of the fair market value of such property or its cost basis to the distributing corporation. ${ }^{14}$

9. INT. Rev. CODE of 1954, §§118, 362(c).

10. 339 U.S. 583 (1950).

11. G.C.M. 16952, 1937-1 Cun. Bunc. 133; Frank Holton \& Co., 10 B.T.A. 1317 (1928), acq., VIIII-8 CUM. BuLL. 21.

12. Derived generally from Int. Rev. Code of $1939, \$ 115$ (a), (b), (d), (e), (j).

13. As under prior law, earnings will support a "dividend" to the extent of an accumulation after February 28, 1913, or to the extent of earnings in the year of distribution even though there be an accumulated deficit. INT. REv. CODE of 1954, $\S 316$.

14. ALI Fed. Income TAX Stat. $\$ X 540$ (Feb. 1954 Draft), establishes a precedent for the new $\$ 301$, INT. REv. CODE of 1954. The comments at 279-82 indicate a purpose to close two loopholes: First, where the value of property in the hands of a subsidiary exceeds its cost basis, it was possible under prior law to pay a minimum tax on the intercorporate property dividend to the parent, which could then sell the property at a "stepped up" basis. But cf. Commissioner v. Transport, Trading \& Terminal Corp., 176 F.2d 570 (2d Cir. 1949), cert. denied, 338 U.S. 955 (1950). Second, while this result is avoided by the new rule requiring a carryover of cost basis to the parent, that rule would also permit a shifting of a prospective loss from subsidiary to parent. Hence, the alternative rule that the amount of the property dividend will be the lower of fair market value or the subsidiary's cost basis. 
At the other end of the distribution spectrum is the complete liquidation which, under Section 331 (a) (1), ${ }^{15}$ still produces solely capital gain or loss to the shareholder. In the middle of the spectrum is the distribution in partial redemption of only a part of the stock, and this is the historic area of conflict in which the Treasury Department contends for "dividend equivalence" and the taxpayer claims the benefits of a capital transaction. ${ }^{16}$

The new law concedes that a "partial liquidation" which has good business purpose will be treated as a capital transaction, but it sharply limits the area of such a partial liquidation. ${ }^{17}$ The statutory technique combines two provisions: Section $331(\mathrm{~b})$ provides that a partial liquidation is to be treated solely as a capital (non-dividend) transaction; and Section 346 defines the "partial liquidation" as (a) one of a series of distributions in complete liquidation of all of the stock, or (b) a distribution and redemption of a part of the stock if it is "not essentially equivalent to a dividend" and if such distribution "occurs within the taxable year in which the plan is adopted or within the succeeding taxable year."

One of the purposes of the latter definition is to give statutory approval to the judicial principle of the "corporate contraction." The Tax Court had held that, where a corporation sold a part of its business and distributed the proceeds, there had been a genuine contraction and the redemption was to be treated as a capital transaction. ${ }^{18}$ This factual situation is formalized as an example in Section 346(b) which guarantees capital treatment for any distribution which is (a) attributable to the disposition of a business conducted for the preceding five years if (b) the distributing corporation will continue to operate another separate business which also had been conducted for the preceding five years. As Section 346(a) (2) specifically states that a partial liquidation is "not limited to" the requirements of Section $346(\mathrm{~b})$, one may expect that case law will approve variations and eventually expand the area of the partial liquidation. ${ }^{19}$

15. Derived from Int. Rev. Code of $1939, \S 115$ (c).

16. For general discussion, see Nolan, The Uncertain Tax Treatment of Stock Redemptions: A Legislative Proposal, 65 Harv. L. Rev. 255 (1951); Dean, The New Section 115(g) Regulations, 11 N.Y.U. AnN. TAX INST. 587 (1953).

17. INT. Rev. CoDE of $1954, \S 331$ (b) 346.

18. Joseph W. Imler, 11 T.C. 836 (1948) ; L. M. Lockhart, 8 T.C. 436 (1947) ; Samuel A. Üpham, 4 T.C. 1120 (1945) ; Nolan, supra note 16, at 264; Miller, Stock Redemptions, 6 N.Y.U. ANN. TAX INST. 307, 315 (1948).

19. The inherent difficulty in measuring "dividend equivalence" at the shareholder level by the presence or absence of a contraction motive at the corporate level is reflected in the ALI Fed. Income TAX STAT. comments, at 205-08 (Feb. 1954 Draft). After extensive study, the ALI Policy Committee concluded that "tax treatment of distributions in partial liquidation should be determined with regard solely to their effect upon the shareholders." Id. at 208. 
Assuming that the surrender of a part of the stock in a partial liquidation does not fit within the rather narrow requirements of Section 346(b), the distribution then enters that "no man's land" of dividend equivalence which, before 1950, was ruled solely by Section $115(\mathrm{~g}){ }^{20}$ The essence of that provision was that any distribution in partial liquidation would be taxed as a dividend if the stock was redeemed "at such time and in such manner as to [be] . . . in whole or in part essentially equivalent to the distribution of a taxable dividend." This loophole-closing provision was supplemented in 1950 by legislation designed to remedy the device exemplified by Commissioner v. Trustees of John Wanamaker. ${ }^{21}$ This so-called Wanamaker amendment treated the sale of stock of a parent corporation to its subsidiary (defined as at least 50 per cent controlled) ${ }^{22}$ as a redemption by the parent of its own stock. The need for further preventive legislation was pointed up by the decision in Emma Cramer ${ }^{23}$ in which the Tax Court held that the taxpayer's sale of stock of one controlled corporation to another controlled corporation was not the equivalent of a redemption by the purchasing corporation. The new Section 304 attempts to deny to others the results achieved in the Emma Cramer decision by providing that a sale of stock of one corporation to another, where both are "controlled" (to the extent of at least 50 per cent) by the taxpayer, is to be treated from the taxpayer's standpoint as a redemption of the stock of the acquiring corporation and, from that corporation's standpoint, as a contribution to its capital. ${ }^{24}$

There is doubt that Section 304 achieves its full purpose. As later indicated, ${ }^{25}$ under Section 337 a corporation may adopt a plan of liquidation, sell its assets, and be free of tax at the corporate level if the sales proceeds are distributed in a complete liquidation before the expiration of 12 months from the date of adoption of the plan of liquidation. It is conceivable that a taxpayer owning all of the stock of corporations $A$ and $B$ could direct that $A$ sell all of its assets (having value in excess of

20. Int. Rev. Code of $1939, \S 115(\mathrm{~g})$ is carried forward, with amendments, in INT. Rev. CODE of 1954, $\$ \$ 302,303,304$. See note 16 supra.

21. 178 F.2d 10 (3d Cir. 1949), held $\$ 115$ (g) inapplicable to a sale of stock of a parent corporation to its wholly owned subsidiary. Revenue Act of 1950, $\$ 208$ (a), 64 Stat. 931 (1950), closed the loophole.

22. INT. REv. CODE of 1954, §304(c) defines "control" as ownership of $50 \%$ of the voting stock or $50 \%$ of the value of all classes of stock. The taxpayer will be deemed to control a subsidiary if at least $50 \%$ of its stock is owned by a parent at least $50 \%$ of the stock of which is in turn owned by the taxpayer. The taxpayer is also charged with "constructive ownership" under $\$ 318$. See note 37 infra.

23. 20 T.C. 679 (1953)

24. This provision closely follows the recommendation in ALI FED. INCoME Tax Stat. \& X532 (Feb. 1954 Draft).

25. See text at note 99 infra. 
cost basis) to $B$ for cash and thereafter distribute the proceeds to the taxpayer in complete liquidation of $A$. Under Section 337, $A$ would not realize taxable gain upon the sale of its assets; the distribution in complete liquidation of $A$ would not be a "sale" as contemplated by Section 304; the taxpayer should receive the liquidation distribution from $A$ as a capital transaction; ${ }^{26}$ and $B$ thereafter would hold assets at a stepped-up cost basis equal to its purchase price, which exceeds the prior basis to $A$. Such a transaction would certainly have all of the characteristics of tax avoidance, but no more so than was the case in Emma Cramer and Commissioner v. Trustees of John Wanamaker. It would seem, therefore, that the complexity of modern tax statutes is such that a door closed by one provision is inadvertently opened by another. ${ }^{27}$

As already indicated, the former Section $115(\mathrm{~g})$ had the original function of closing the loophole whereby redeeming stockholders sought to convert dividend distributions into capital gain transactions. Inevitably, this statutory dragnet caught partial liquidation distributions which were based upon reason and not upon tax avoidance. The prime example was the case of the executor administering an estate whose chief asset was the stock of a close corporation. Perhaps substantial estate tax was owing by reason of the value of the stock, but no cash was available to pay the estate tax unless cash within the corporation was distributed to the executor. Under Section $115(\mathrm{~g})$ the entire amount of such a distribution might be subject to tax at ordinary rates even though stock was surrendered in a partial liquidation. ${ }^{28}$ Accordingly, in 1950 an amendment was enacted which exempted from "dividend equivalence" certain partial liquidation distributions up to the amount of the death taxes and interest thereon. ${ }^{29}$ The new Section 303 has extended the amount of this remedial provision to include also the

26. Pursuant to a complete liquidation "as in full payment in exchange for the stock." INT. REV. CODE OF 1954, §331(a) (1).

27. Often not one but numerous doors are opened to tax avoidance. Assume that controlled corporation $B$ has neither earnings nor liquid assets, yet purchases the stock of controlled corporation $A$ from the taxpayer by giving him installment notes which are later paid with cash which passed from $A$ to $B$ (via intercorporate dividends or tax-free liquidation under $\$ 332$ ). Under $\$ 304$ the "constructive redemption" is charged to $B$, which has no earnings; hence, under $\$ \$ 301$ and 316 there could be no dividend distribution to the taxpayer.

28. But see Henry V. Foster Estate, 3 CCH T.C.M. 249 (1944), in which the executor avoided dividend equivalence although the redemption caused less than a $1 \%$ change in his proportionate interest in the corporate stock.

29. Revenue Act of $1950, \S 209$ (a), 64 STAT. 932 (1950), as amended by Revenue Act of 1951, \$320(a), 65 STAT. 498 (1951), limited the exemption from "dividend equivalence" to a stock which comprised at least $35 \%$ of the decedent's gross estate, provided that the redemption occurred within 3 years and 90 days from the date the Federal Estate Tax Return was filed. For general discussion, see Dean, snpra note 16 , at 592 . 
amount of funeral and administration expenses allowed as a deduction for estate tax purposes. ${ }^{30}$

The original framework of the old Section $115(\mathrm{~g})$ appears in the new Section 302 which not only closes loopholes but in addition provides remedies. The American Law Institute model draft had recommended legislation which would exempt from dividend equivalence any redemption which was sufficiently "disproportionate" as between shareholders, the fundamental theory being that dividend equivalence required that the distribution be substantially pro rata among those who owned the common stock. ${ }^{31}$ Section 302 adopts this approach and provides that a distribution in redemption of stock will be treated as a sale or exchange (and thus not treated as a dividend) in any of the cases specified in subsection (b) : ${ }^{32}$

1. If the redemption is not essentially equivalent to the distribution of a dividend. ${ }^{33}$

This rule apparently is intended as a restatement of the generalities of the prior Section $115(\mathrm{~g})$, and the committee report ${ }^{34}$ clarifies somewhat the confusion created by prior case law by stating that the inquiry into dividend equivalence "will be devoted solely to the question of whether or not the transaction by its nature may properly be characterized as a sale of stock . . . [and that] . . . the presence or absence of earnings and profits of the corporation is not material."

2. If the redemption is substantially disproportionate; meaning that after the redemption the particular shareholder's percentage of ownership of outstanding voting and common stock, must be less than 80 per cent of such ownership percentage before the redemption, and he must then own less than 50 per cent of the total combined voting power. ${ }^{35}$

With admirable foresight Congress has further provided that the 80 per cent disproportion rule will be voided if the single redemption is one

30. Other changes in $\$ 303$ are that the stock (part of which is redeemed) will qualify if its value is at least $35 \%$ of the gross estate or $50 \%$ of the taxable estate; that stock of two or more corporations, each comprising at least 75\% of outstanding stock, will be treated as a single stock; that qualifying stock also includes new stock issued after death in a tax-free exchange or distribution (thereby permitting creation of non-voting stock to be redeemed without affecting continuing voting control); and that the period for redemption is extended to 60 days after final decision of the Tax Court with respect to an estate tax issue duly raised by petition filed. Draft).

31. ALI FED. Income TAX Stat. \$X530, comments, at 269 et seq. (Feb. 1954

32. But any distribution not within $\S 302(\mathrm{~b})$ will automatically "be treated as a distribution of property to which section 301 applies" ( $\$ 302(d))$, i.e., as a dividend to the extent of the corporate earnings available for distribution ( $\$ 316)$.

33. INT. REV. CODE OF 1954, \&302(b) (1).

34. SEN. REP. No. 1622, 83d Cong., 2d Sess. 234 (1954).

35. INT. Rev. CoDe of 1954, §302(b) (2). 
of a series which, telescoped together as one, would not be disproportionate.

3. If 100 per cent of the stock owned by the shareholder is redeemed and thereafter he holds no interest in the corporation. ${ }^{36}$

In establishing these several percentage requirements, Congress realized that a shareholder might (a) initially transfer a part of his stock to a related person or to a controlled organization, (b) thereafter have the balance of his stock redeemed, and (c) then claim literal compliance with the percentage requirements. This avoidance procedure has been effectively nullified by the rules of "constructive ownership" in Section 318 which "attribute" to the taxpayer stock owned by certain relatives and by organizations which he controls. ${ }^{37}$

As a working example, consider the case of a corporation with substantial surplus and 100 shares of outstanding common stock, of which 75 shares are owned by $A$ and 25 shares are owned by $B$. If the corporation redeems 51 shares of $A^{\prime}$ 's stock, leaving him with but 24 shares, he will have met the disproportion test ${ }^{38}$ because, after the redemption, his interest will be less than 80 per cent of what it was before the redemption and he will then own less than 50 per cent of the voting power. But this is true only if $B$-who owns the other 25 shares-is not within the area of relationship to $A$ as laid down by the constructive ownership rules of Section 318. If $B$ were the son of $A$, then $A$ would constructively own 100 per cent of the stock both before and after the redemption, and the 80 per cent disproportion rule would not be met.

However, the new Code recognizes a proper situation where the father might wish to retire from the business and leave his son to take the investment risks attendant upon his own management. For this reason, Section 302 (c) provides that ownership within the family will not be attributed to another family member who (a) surrenders all of his stock in redemption, (b) thereafter has no interest in the corpora-

36. INT. Rev. CODE of 1954, §302(b) (3). An additional exception to dividend equivalence, not discussed in the text, is the redemption "of stock issued by a railroad corporation . . pursuant to a plan of reorganization under section 77 of the Bankruptcy Act." INT. REv. CODE of 1954, \$302(b) (4).

37. A taxpayer is deemed to constructively own shares actually owned by (1) members of his family (spouse, children, grandchildren and parents), by (2) a partnership or estate (to the extent of his interest therein), by (3) a trust to the extent of his beneficial interest (but a grantor who is a "substantial owner" will be attributed with all the stock of the trust), and by (4) a corporation to the extent of his pro rata interest therein if he owns $50 \%$ or more in value of its stock. Comparable treatment is recommended in ALI FED. Income TAX STAT. \$X533, comments, at 27 (Feb. 1954 Draft).

38. Under $\$ 302(b)(2)$. 
tion (including as officer, director or employee) other than as a creditor, (c) does not acquire any such interest (other than by bequest or inheritance) within ten years from the distribution date, and (d) agrees with the Commissioner of Internal Revenue that the limitation period for assessment may be reopened if any such interest is acquired within the ten-year period. ${ }^{38}$

Much study has been given to this problem of paying off the retiring, older generation and providing for the continuation of the corporate business by the younger generation which has succeeded to the business responsibilities. Under prior law, the Treasury Department has conceded that the retiring generation might surrender its common stock for new preferred stock (as a reorganization by way of a recapitalization) and that such exchange would be tax-free if there were no present intention to redeem the new preferred stock. ${ }^{40}$ While this procedure had many advantages, it had the obvious disadvantage that the preferred stock investment of the retiring generation would still be subject to the business policies and determinations of the younger generation who would then control and manage the corporation. Section 302 now functions as a remedial provision which permits the retiring generation to recapture its stock investment in a cash redemption, the proceeds of which will no longer be subject to the risks of the business managed by others, subject only to the tax payable upon the resulting capital gain, if any.

\section{Stock Dividend Distributions}

The thin and wavering line between taxable and nontaxable stock dividends has been substantially erased by Section 305 which provides that a distribution of stock by the issuing corporation will be tax-free in all cases except where (a) the distribution is in discharge of preference dividends or (b) the shareholders may elect to take cash or other property in lieu of stock. The hallmark decisions beginning with Eisner $v$. Macomber ${ }^{41}$ and extending through Koshland v. Helvering, ${ }^{42}$ Helver-

39. The effect of $\S 302$ (c) is to make an exception to attribution of ownership between family members if the redeeming member retires completely from the business. But even this relief is withdrawn if within ten years before the redemption the distributee has (a) received the shares redeemed from another family member or (b) transferred other shares to another family member. $\$ 302(\mathrm{c})(2)(\mathrm{B})$. This "exception to the exception" is to prevent (a) Husband giving one-half of his stock to Wife, who thereafter acts as the redeeming shareholder, or (b) Husband giving one-half of his stock to Wife, and thereafter Husband acts as the redeeming shareholder. SEN. REP. No. 1622, 83d Cong., 2d Sess. 236 (1954).

40. Elmer W. Hartzell, 40 B.T.A. 492 (1939), acq., 1939-2 CuM. Bull. 16; Marjorie N. Dean, 10 T.C. 19 (1948), acq., 1949-1 Cun. Bunc. 1.

41. 252 U.S. 189 (1920). However, this constitutional landmark still functions to prevent new legislation which might attempt to tax a common-on-common stock dividend.

42. 298 U.S. 441 (1936). 
ing v. Goweran, ${ }^{43}$ and Wiegand v. Commissioner ${ }^{44}$ are no longer significant. With the exceptions mentioned any stock dividend is now received tax-free.

At first blush this revolution in tax treatment of stock dividends would seem to open the door to the tax avoidance exemplified by Chamberlin v. Commissioner. ${ }^{45}$ In that case a controlling stockholder required his corporation to issue to him a preferred stock which, standing alone, represented a tax-free distribution under Strassberger $v$. Commissioner. ${ }^{46}$ However, the preferred stock had been tailored to meet the needs of insurance companies which had committed themselves to the purchase of such stock following its receipt by the taxpayer. The taxpayer claimed that the sale of the preferred stock to the insurance companies produced only capital gain, but the Treasury contended that an overall view of the stock distribution and its related sale required the conclusion that there had been a distribution equivalent to a dividend, and that the insurance companies served only as a medium for distribution of corporate earnings. The taxpayer's contention was repudiated by the Tax Court ${ }^{47}$ but approved by the Court of Appeals for the Sixth Circuit. ${ }^{48}$

Such a wholesale "bail out" of corporate earnings was considered to require legislative action. The House of Representatives proposed the solution of an 85 per cent surtax against the corporation if it redeemed the preferred stock within ten years of its issuance as a taxfree dividend. ${ }^{49}$ Perhaps more than any other provision of the House bill, it was this provision which was most strongly attacked during the hearings before the Senate Committee on Finance. ${ }^{50}$ The Treasury

43. 302 U.S. 238 (1937).

44. 194 F.2d 479 (3d Cir. 1952). For full discussion of the stock dividend problems, see Lowndes, The Taxation of Stock Dividends and Stock Rights, 96 U. of Pa. L. Rev. 147 (1947) ; Dean, The Stock Dividend, 32 TAxes 586 (1954) ; ALI FEd. Income TAX Stat. comments, at 194 et seq. (Feb. 1954 Draft).

45. 207 F.2d 462 (6th Cir.), cert. denied, 347 U.S. 918 (1953).

46. 318 U.S. 604 (1943), holding nontaxable a dividend of preferred on common stock because there was no change in the proportionate interests held by the stockholders.

47. C. P. Chamberlin, 18 T.C. 164 (1952).

48. See note 45 supra.

49. H.R. 8300, 83d Cong., 2d Sess. $\$ 309$ (1954) ; H.R. Rep. No. 1337, 83d Cong., 2d Sess. A 91 (1954).

50. Hearings before Senate Committee on Finance on H.R. 8300, 83d Cong., $2 \mathrm{~d}$ Sess. 359 (1954). "It appears that section 309 [of the House bill] actually would encouarge bail-outs by spelling out the exact steps by which its provisions may be avoided. It becomes necessary merely to find an investor who is willing to accept a ten-year maturity on the preferred stock, approximately two years longer than the maturity in the Chamberlin case. . . [Moreover], the burden of the tax may fall upon those who had no part in the distribution or receipt of the dividend in preferred stock or in the bail-out transaction." 
Department, as the chief proponent for the 85 per cent corporate surtax, was forced to retreat and to accede to the recommendation contained in the ALI model draft and now made a part of the new Code in Section 306.51

The new Code has created a new type of security known as "Section 306 stock," which is defined ${ }^{52}$ as (a) stock distributed tax-free under Section 305 ("other than common stock issued with respect to common stock"), or (b) stock ("which is not common stock") received pursuant to a corporate reorganization (Section $368(\mathrm{a})$ ) or a corporate division (Section 355) if "the effect of the transaction was substantially the same as the receipt of a stock dividend, or the stock was received in exchange for section 306 stock." Stock so labeled carries the potential danger that upon its later sale or redemption the proceeds received may be fully taxed as ordinary income. ${ }^{53}$ Thus, the corporate "bail out" is attacked at its proper level-that of the shareholder who has caused the tax-free issuance of the stock dividend in order that its later sale and redemption might be the procedure for bailing out corporate earnings on a capital gains basis.

Like any loophole-closing measure, a general application of Section 306 would create inequities unless proper exceptions were provided. The only exceptions ${ }^{54}$ to ordinary income treatment under Section 306 are (1) if there are no current or accumulated earnings at the time of the distribution of the tax-free stock, (2) if the later sale of the Section 306 stock is to a person whose stock ownership is not attributable to the seller (under Section 318) and such sale effects a termination of the seller's entire stock interest (including stock constructively owned), (3) if a later redemption of the stock terminates the shareholder's entire stock interest, (4) if the later redemption of the stock qualifies as a complete or partial liquidation under Sections 331 and 346, or (5) if the Commissioner is satisfied that the distribution and later sale or redemption were not motivated by tax avoidance purposes, e.g., the stockholder involved had only a minority stock interest and had no substantial voice in the distribution. Draft).

51. ALI Fed. Income TAX Stat. §X519, comments, at 247 et seq. (Feb. 1954

52. INT. REv. CODE OF 1954, \$306(c).

53. A redemption of Section 306 stock is treated as a distribution under $\$ 301$ $(\$ 306(a)(2))$, and presumably it will carry all the attributes of a dividend, including the dividend-received exclusion (\$116) and credits as to individual ( $\$ 34$ ) and corporate $(\$ 243)$ distributees. However, the proceeds from sale of Section 306 stock are simply taxed as ordinary income to the extent of a ratable share in corporate earnings at the time the stock originally was distributed (\$306(a) (1) (A)); any balance of proceeds constitutes a reduction of cost basis, and any excess over basis is taxed as capital gain ( $\$ 306(\mathrm{a})(1)(\mathrm{B}))$.

54. INT. REv. CODE OF 1954, \$306(b). These exceptions should be read in the light of the discussion in SEN. REP. No. 1622, 83d Cong., $2 \mathrm{~d}$ Sess. 241 et seq. (1954). 
While a gift or other tax-free disposition of the Section 306 stock will not create income tax consequences at that time, nevertheless the transferee will be subject to the same tax consequences as would his transferor upon sale or redemption of the stock. However, the Section 306 characteristics will disappear in the hands of the purchaser for value, heir, legatee, or other person who obtains a new cost basis upon acquisition, and those characteristics may also be "purged" if the Section 306 stock is later exchanged for common stock of the same corporation. ${ }^{55}$

As in the case of other concepts which are entirely new in the 1954 Code, this explosive Section 306 has a blast area which cannot be judged accurately at this time. Doubtless the Commissioner's Regulations will attempt to extend its effect as far as possible. However, one can expect that the ingenuity of the taxpayer will eventually challenge the Commissioner within the area of Section 306 and the resulting litigation might well produce a changing pattern of questions and decisions reminiscent of the now obsolete stock dividend decisions.

For example, Section 306 stock is negatively defined as "other than common stock issued with respect to common stock." Does this include a limited common stock-one which is limited (but not preferred) as to the amount to be received at liquidation, the annual dividends to be paid and the voting power to be exercised? ${ }^{56}$ If, in a recapitalization, common stock is surrendered in exchange for a package of new common stock and new preferred stock, will the distribution of the preferred stock necessarily have "the effect . . . of a stock dividend" and, thus, qualify as Section 306 stock merely because corporate surplus was capitalized in the amount of the preferred stock? ${ }^{57}$ Is there any conceivable objection to the donation of Section 306 stock to an exempt organization, followed by a redemption of that stock in the hands of that exempt organization?

55. INT. Rev. CoDE of 1954, $\$ 306$ (c) generally limits Section 306 stock to stock in the hands of the person who received it originally from the distributing corporation. The only exceptions are that (a) the distribution must be such that, had cash been distributed, it would have been taxed as a dividend (i.e., the corporation must have had earnings); and (b) a transferee who takes his transferor's cost basis (as in the case of gift or tax-free exchange) will also take over the Section 306 characteristics.

56. Rev. Ruling 54-65, 1954 INT. REv. BuL. No. 8, at 5 (1954), held that two common stocks representing different underlying investment portfolios of the same investment company were not "like stock in the same corporation." While this recent pronouncement deals solely with the common-for-common exchange under $\S 1036$ (Int. Rev. Code of $1939, \S 112$ (b) (2)), it expresses a view which probably will carry over to $\$ 306$.

57. Cf. Zenz v. Quinlivan, 213 F.2d 914 (6th Cir. 1954), in which a sole shareholder sold part of her stock and shortly thereafter the balance was purchased "as treasury stock which absorbed substantially all of the accumulated earnings and surplus of the corporation." The court held that the coincidence of the amounts of redemption and earnings did not create "dividend equivalence." 
It is possible that Section 306 might be avoided altogether if the courts require only technical compliance. Thus, one who owns all of the common stock of Corporation $A$ might transfer that stock to a new Corporation $B$ in exchange for common and preferred stock of $B$. $B$ could thereafter liquidate its new subsidiary $A$ and thereby acquire its assets. The underlying assets would thereafter be represented by common and preferred stock of $B$ which had no earnings when its stock z'as issued; hence, by the literal terms of Section 306 (c) (2), the preferred stock would be exempt from the consequences of Section 306 stock. ${ }^{58}$

Or perhaps the stockholders of Corporation $A$ could form Corporation $B$ which would (a) issue a small amount of common stock to the incorporating stockholders for cash, and (b) issue voting preferred stock for all of the assets of $A ; A$ then, as a part of a reorganization plan (under Section 368(a)(1)(C)), would dissolve and distribute the preferred stock. ${ }^{59}$ These are transactions with the purpose of defeating the penalizing Section 306. Such a tax avoidance purpose, when not accompanied by a bona fide business reason, often has been sufficient to nullify the fact of technical compliance. ${ }^{60}$

\section{Effect Upon the Distributing Corporation}

The judicial rule of General Utilities \& Operating Co. v. Helver$i n g^{61}$ has been partially adopted in Section 311(a), which states that no gain or loss will be realized by the distributing company upon a distribution of its property and stock, which has a cost basis different from its fair market value. However, there are several exceptions, one requiring that the corporation be taxed on the excess of normal inventory value over the lower "last in, first out" inventory value, ${ }^{62}$ and another requiring that the corporation be taxed on the excess of the fair market value of installment obligations distributed over the tax basis of such obligations. ${ }^{63}$

58. It is possible that the courts might construe each step as one of a series of transactions under a single plan of reorganization of corporation $A$. William M. Liddon, 22 T.C. No. 150 (Sept. 21, 1954). Under this view, the new preferred stock issued by corporation $B$ (a party to the reorganization) might qualify as Section 306 stock under $\$ 306$ (c) (1) (B).

59. This transaction would be subject to the same arguments expressed in note 58 supra.

60. Gregory v. Helvering, 293 U.S. 465 (1935) ; Commissioner v. Transport Trading \& Terminal Corp., 176 F.2d 570 (2d Cir. 1949), cert. denied, 338 U.S. 955 (1950).

61. 296 U.S. 200 (1935)

62. INT. Rev. CODE of 1954, §311(b).

63. INT. REv. CODE of 1954, §453(d). But deferred income covered by installment obligations will not be accelerated by distribution in a complete liquidation under $\$ 332$ (tax-free liquidation of subsidiary) or $\$ 337$ (see text at note 99 infra). A third exception deals with assumption of liabilities in excess of cost basis, discussed in text following note 87 infra. 
Of more current interest is the attempt to legislate in the field covered by the recent decisions in Commissioner $v$. Hirshon Trust ${ }^{04}$ and Commissioner v. Godley's Estate. ${ }^{65}$ These decisions hold that corporate earnings are reduced by only the cost basis of a property dividend rather than by its higher fair market value, and that, if earnings are sufficient to cover the lower cost basis, the full fair market value of the property dividend will be taxable to the shareholder even though such value may exceed corporate earnings. Section 312(a) confirms the judicial rule that earnings will be reduced only by the cost basis of the property dividend, but it implicitly overrules the Hirshon and Godley decisions in limiting the amount taxable to the shareholder to the cost basis rather than the fair market value of the property dividend if corporate earnings are sufficient only to cover the cost basis. ${ }^{66}$

Other loophole closures which appear in Section 312 deal generally with increasing corporate earnings by reason of the distribution of unrealized receivables or fees and the excess value of inventory, ${ }^{67}$ and the distribution of FHA loan proceeds. ${ }^{68}$

\section{CoRPorate REORganIZATIONS}

The House bill was notorious chiefly for its revisions of the corporate reorganization pattern. Corporations which could not qualify as "publicly held" were not entitled to the benefit of a tax-free merger. ${ }^{69}$ About all that remained of prior law was the stock-for-stock and the stock-for-assets forms of reorganization as under prior Section $112(\mathrm{~g})(1)(B)$ and $(C){ }^{70}$ respectively. After 35 years of judicial interpretation of the reorganization provisions, and the establishment of a substantial amount of clarity, the tax bar feared that it might be

64. 213 F.2d 523 (2d Cir. 1954).

65. 213 F.2d 529 (3d Cir. 1954).

66. Sen. Rep. No. 1622, 83d Cong., 2d Sess. 248 (1954). However, the tentative regulation, $\$ 1.316-1(\mathrm{a})(2)$, issued by the Commissioner interprets $\$ 312(\mathrm{a})$ differently, disregarding the Senate Report, and continues to apply the Hirshon and Godley decisions to their full effect. Int. Rev. Proposed Regulations, Corporate Distributions and Adjustments, \$1.316-1(a) (2), 19 FED. REG. 8253 (1954).

67. Under INT. REv. CODE of 1954, $\$ 312$ (b), upon distribution of inventory and unrealized receivables or fees the corporate earnings will be increased by the excess of fair market value over cost basis, and decreased by the lesser of (1) the fair market value of the inventory and unrealized receivables distributed, or (2) the corporate earnings increased as aforesaid.

68. Under INr. REv. CODE of 1954, $\$ 312(j)$, the excess of loans over the cost basis of property securing such loans, guaranteed or insured by the United States or its agency such as FHA, will increase corporate earnings and hence create a source for dividend distribution if and when the loan proceeds are distributed.

69. H.R. 8300, 83d Cong., 2d Sess. §354(b) (1954) ; H.R. REp. No. 1337, 83d Cong., 2d Sess. A 126 (1954). A corporation was "publicly held" only if $50 \%$ of its stock or voting power was not held by ten or fewer shareholders. H.R. 8300, supra, $\S 359$ (a).

70. H.R. 8300, 83d Cong., 2d Sess. $\$ 359$ (b),(c),(d) (1954). 
plunged once again into the uncertainties of new reorganization concepts. However, these fears were removed by the Senate, and the Code as enacted has substantially continued the prior reorganization law, with a few helpful amendments. ${ }^{71}$

The type " $B$ " stock-for-stock reorganization "2 now permits a form of "creeping control" whereby acquiring Corporation $X$ initially may purchase, for example, 30 per cent of $Y$ stock for cash and later acquire 55 per cent of the $Y$ stock with voting stock of $X$, thereby being in the required position of controlling more than 80 per cent of the stock of the acquired corporation. ${ }^{73}$ The second-step 55 per cent stockfor-stock acquisition will be tax-free, as will any similar stock-for-stock acquisition after the acquiring Corporation $X$ has established at least an 80 per cent control position. ${ }^{74}$

The type " $C$ " stock-for-assets reorganization ${ }^{75}$ was interpreted rather strictly in Groman v. Commissioner ${ }^{78}$ and Helvering v. Bashford, ${ }^{77}$ the Supreme Court holding that the reorganization exchange was taxable if the acquired assets were transferred to a subsidiary of the acquiring corporation (whose stock had been used in the acquisition), or if the acquiring corporation used not its stock but the stock of its parent corporation as the consideration for acquiring the assets. The new Section 368(a)(2) (C) now permits the assets to reside in a controlled corporation other than one the stock of which is used to acquire the assets. ${ }^{78}$

The prior type " $C$ " stock-for-assets reorganization required that "solely stock" be used to acquire assets. The new Code permits up to 20 per cent of the fair market value of the transferor's assets to be acquired with cash or other property. ${ }^{79}$ For this purpose, "other property" includes the assumption of liabilities of the transferor corporation, and, if stock is used to acquire assets subject to liabilities which are 20

71. SEN. ReP. No. 1622, 83d Cong., 2d Sess. 51, 272 (1954).

72. INT. REv. CODE OF 1954, $\$ 368$ (a) (1) (B).

73. INT. REv. CODE of 1954, §368(c).

74. The approval of creeping control follows the recommendation in ALI FED. Incosse TAX Stat. \$X601, comments, at 308 et seq. (Feb. 1954 Draft). Contrary to the ALI recommendation, but consistent with prior law, the new \&368(a) (1) (B) continues to require that the acquiring corporation give solely voting stock.

75. INT. Rev. CodE of 1954, §368(a) (1) (C).

76. 302 U.S. 82 (1937).

77. 302 U.S. 454 (1938).

78. Under $\$ 368$ (a) (1) (C), the acquiring corporation may be the subsidiary and the stock of its parent may be used as the consideration, or, under $\$ 368$ (a) (2) (C), the parent may acquire the assets and thereafter transfer them to its controlled subsidiary. A precedent is ALI FED. INCOME TAX STAT. $\$ X 602$ (d), comments, at 315 (Feb. 1954 Draft).

79. INT. Rev. CODE OF 1954, §368(a) (2) (B). 
per cent or more of gross assets, then no cash can be used in lieu of stock. ${ }^{80}$

These liberalizing amendments will benefit those expanding corporations which have realized that a new business might better be acquired with cash than with new stock. New stock means more shareholders and the need for more earnings (after taxes) to pay additional dividends under a pre-established dividend policy. It may be more conservative to purchase the new business with borrowed money and, instead of paying out nondeductible dividends, to disburse deductible interest. However, a conflict may result if some of the selling shareholders insist upon tax-free stock; and it is here that the policy of "creeping control" may achieve the median line: the acquiring corporation might purchase as much stock as possible for cash, or buy up to 20 per cent of assets for cash, following which the acquisition may be completed with tax-free stock which would satisfy those shareholders of the transferor corporation who insist upon stock.

\section{Corporate Divisions}

Closely related to the reorganization field is the new Section 355 which provides that no gain or loss will be recognized if a corporation distributes stock or securities of a "controlled" corporation to its shareholders with respect to their stock, or to its security holders in exchange for their securities. This provision continues, within a more limited area, the so-called tax-free "spin-off" permitted by Section 112 (b) (11) of the 1939 Code. $^{81}$

This divisive distribution is conditioned, however, upon the requirements that (a) the transaction must not have been "used principally as a device for the distribution of the earnings and profits" 82 (as would be indicated by prior negotiation or agreement for sale of the distributed securities); (b) the distributing corporation must not have acquired control of the corporation, whose stock is distributed, through a taxable transaction within the prior five years; (c) both businesses must have been engaged in a trade or business which was active for the prior five years and which also was not acquired in a taxable transaction within those prior five years; and (d) all of the stock or securities of the controlled corporation must be distributed.

A revolutionary change is that under this new Section 355 the distribution may be disproportionate among the shareholders of the

80. However, in other respects the transferee's assumption of the transferor's indebtedness is to be disregarded. INT. REv. CODE OF 1954, §368(a) (1) (C).

81. The concept of a corporate division was recommended in more general terms in ALI FED. INCOME TAX STAT. \$ X603, comments, at 315 et seq. (Feb. 1954 Draft).

82. INT. Rev. Code of 1954, $\$ 355$ (a) (1) (B). 
distributing company, ${ }^{83}$ thereby permitting a tax-free division of two businesses between two shareholder groups.

While at first glance this provision appears to favor the taxpayer, actually it restricts the scope of the spin-off as permitted under the prior Section $112(b)(11)$. Under that section it was not necessary that the separate businesses have been in existence for five years. Moreover, the necessity of two businesses, each engaged in "the active conduct of a trade or business," may well restrict the assets which might be divorced and distributed in a corporate division of this nature. Thus, under the prior Section 112(b) (11) it was possible, with administrative approval, for an operating business to transfer its real estate to a new corporation the stock of which was "spun off" to shareholders. There is indication that under the new Section 355 administrative approval will be withheld from such a corporate division unless for at least five years the real estate was occupied by others than the parent corporation and the parent undertook the "active conduct" of a building operator.

\section{The Area of Taxable "Boot"}

Only stock and securities may be received tax-free under the various tax-free exchange provisions previously discussed. Cash, property and their equivalent continue to be taxable "boot" which will be taxed to the extent of any gain realized from the exchange. ${ }^{84}$ Indeed, the "boot" may be taxed in full if the exchange "has the effect of the distribution of a dividend." 85

While bonds normally would qualify as tax-free securities, under prior law they probably would be taxed as "boot" if received solely in exchange for stock. ${ }^{86}$ The 1954 Code removes all doubts on this score. The new rule is that securities received in a reorganization exchange (under Section 354) or as a distribution in a corporate division (under Section 355) are taxable "boot" except to the extent that their principal amount is offset by the amount of old securities surrendered. ${ }^{87}$

83. Under $\$ 355$ (a) (2) it is unimportant that the stock of the controlled corporation is distributed non-pro rata, or without surrender of stock of the distributing corporation, or that there is no plan of reorganization.

84. INT. REV. CODE of 1954, \$356(a) (1).

85. INT. Rev. Code of 1954, $\$ 356$ (a) (2); Int. Rev. Code of 1939, $\$ 112$ (c).

86. Bazley v. Commissioner, 331 U.S. 737 (1947). But the courts were inconsistent, and a tax-free recapitalization exchange of bonds for stock was approved in Wolf Envelope Co., 17 T.C. 471 (1951), appeal dismissed, 197 F.2d 864 (6th Cir. 1952). An exchange of new bonds for old bonds has been consistently approved as a tax-free recapitalization. Commissioner v. Neustadt's Trust, 131 F.2d 528 (2d Cir. 1942) ; Sen. Rep. No. 1622, 83d Cong., 2d Sess. 268 (1954).

87. INT. Rev. CODE of 1954, §§356(d), 354(a) (2), 355(a) (3). ALI Fed. Income TAX Stat. $\S \mathrm{X} 513$ (a), comments, at 226 (Feb. 1954 Draft), also recom- 
A form of "boot" newly recognized as taxable under the 1954 Code is the assumption of liabilities. Originally, the transferee's assumption of liabilities of the transferor was treated as "boot" or "other property" received by the transferor. ${ }^{88}$ In 1939 the Code was amended to provide that such assumption "shall not be considered as other property or money." 89 This remedy, in turn, produced a loophole whereby, for example, a high-bracket taxpayer borrowed $\$ 200,000$ against a property having a value of $\$ 300,000$ but a cost basis of only $\$ 100,000$; thereafter, the property was transferred tax-free to a controlled corporation which paid off the $\$ 200,000$ debt with corporate income taxed at lower corporate brackets. This loophole has been closed in Section 357 (c) of the new Code which not only reenacts the general rule of prior Section $112(\mathrm{k})$ - that in the absence of a tax avoidance purpose the assumption of indebtedness "shall not be treated as money or other property"-but also provides that gain is realized by the transferor in the amount of the excess of liabilities assumed, plus the amount of liabilities to which the transferred property is subject, over the cost basis of such property. ${ }^{90}$

The recognition of gain measured by the excess of liabilities over cost basis is applicable in other areas as well. Thus, if a corporation owns property which is subject to liabilities in excess of its cost basis, the excess will be taxed as gain to the corporation when it distributes the property. ${ }^{91}$ This rule is applicable to all corporate distributions not in complete or partial liquidation. ${ }^{92}$ The rule applies as well to a distribution of property to shareholders in a "divisive" reorganization within Section $368(a)(1)(D) .{ }^{93}$

\section{CORPORATE LIQUIDATIONS}

The general rules pertaining to corporate liquidation distributions have been continued: a liquidating corporation realizes neither gain nor

mended that securities be received tax-free only to the extent that old securities were surrendered. But the attempt in the ALI model draft, $\$ X 500(\mathrm{~g})$, and H.R. 8300 , $83 \mathrm{~d}$ Cong., $2 \mathrm{~d}$ Sess. $\$ 312$ (c), to define that which qualifies as "securities" was rejected. Under the 1954 Code, as under prior law, the line of demarcation between mere debt and "securities" depends upon the judicially developed rules relating to term of the debt, fixed maturity date, contingency of interest, subordination to other debt, etc. ALI FED. INCOME TAX STAT. supra, comments, at 227 et seq.; Camp Wolters Enterprises, Inc., 22 T.C. No. 94 (1954); Estate of William Bernstein, 22 T.C. No. 169 (1954).

88. United States v. Hendler, 303 U.S. 564 (1938).

89. Int. Rev. Code of $1939, \S 112(\mathrm{k})$.

90. Once again ALI FEd. Income TaX Stat. §X606 (Feb. 1954 Draft), served as a sounding board for the legislative change.

91. INT. REv. CoDE of 1954, §311(c).

92. See note 90 supra.

93. INT. Rev. CODE of $1954, \S 357$ (c). 
loss; ${ }^{94}$ the shareholder is treated as if he had received a "payment in exchange for the stock." ${ }^{05}$ But these general rules are becoming better known for their many exceptions, which have been substantially extended in the new Code. ${ }^{96}$

Under prior law, a liquidating corporation realized gain or loss from its sale of assets even though, thereafter, the sales proceeds were promptly distributed to shareholders. Taxable gain could be avoided by a distribution "in kind" followed by a sale of the property by the shareholders. ${ }^{97}$ But if, before distribution, the corporation had negotiated for the sale of the assets, it might be charged with "constructive gain" even though the mechanics of sale were carried out by the shareholders following the liquidation. ${ }^{98}$

The new Section $337^{90}$ attempts to end all arguments in this area by providing that the liquidating corporation will realize neither gain nor loss from its sale of assets if (a) after June 22, 1954, it adopts a plan of complete liquidation, (b) thereafter sells the assets in question, and (c) within 12 months of the adoption of the plan of liquidation, it distributes all of its assets (with the exception of a reasonable amount retained to meet claims) to its shareholders. This new rule for avoiding tax at the corporate level does not apply with respect to gains from the sale of stock in trade, inventory or other property held primarily for sale to customers in the ordinary course of business, unless such property is attributable to a business which is sold to one person in one transaction. ${ }^{100}$ Nor will the new Section 337 apply to the liquidation of certain corporations which have special characteristics in their tax effect upon shareholders. ${ }^{101}$

The freedom from tax at the corporate level under Section 337 presupposes that, following the complete liquidation, the shareholders will realize taxable gain or loss at their shareholder level. Inasmuch as under Section 332 the liquidation of a subsidiary into its parent cor-

94. INT. Rev. CODE of 1954, $\$ 336$.

95. INT. REv. CODE oF 1954, §331(a) (1).

96. For example, $\$ 341$ of the 1954 Code continues and extends the concept of the "collapsible corporation" which, generally, is an incorporated reservoir for unrealized "ordinary" income that, prior to 1950, could be converted into capital gain by a sale of the stock or a complete liquidation immediately prior to the time of income realization.

97. United States v. Cumberland Public Service Co., 338 U.S. 451 (1950); Glenn v. Burley Tobacco Warehouse, Inc., 207 F.2d 779 (6th Cir. 1953).

98. Commissioner v. Court Holding Co., 324 U.S. 331 (1945).

99. A comparable provision appears in ALI FED. Income TAX Stat. $\$ X 550$, comments, at 283 et seq. (Feb. 1954 Draft).

100. Int. Rev. Cone of 1954, §337(b) (2).

101. INT. REv. CODE of $1954, \S 337$ (c) withholds its benefits from a collapsible corporation ( $\$ 341$ ), or a corporation which liquidates and elects the benefits of $\$ 333$, or a subsidiary which liquidates tax-free into its parent under $\$ 332$. 
poration will not produce gain or loss at the parent-shareholder level, Section 337 (c) (2) requires that gain or loss will be recognized to the selling subsidiary upon its sale of assets prior to its liquidation into the parent organization.

An extension of Section 337 is to be found in what purports to be the "effective date" section but which, in fact, contains a substantive provision which was introduced by the conference committee after the Code had passed through both the House and the Senate. ${ }^{102}$ Under this last-minute provision, the plan of liquidation may be adopted after December 31, 1953 (in lieu of June 22, 1954), and the corporation may sell its assets at any time during 1954, and yet there will be no tax at the corporate level if the liquidation is completed within the calendar year 1954. Thus, a few favored corporations are permitted to escape tax on gains from sales made substantially before the effective date of the 1954 Code.

Another major revision concerns the cost basis to be assigned to assets received upon liquidation of a subsidiary corporation where the stock of that subsidiary was purchased solely for the purpose of obtaining the underlying assets. Over a period of years the courts had developed a somewhat uncertain rule, best represented in Kimbell-Diamond Milling Co. v. Commissioner, ${ }^{103}$ to the effect that the price paid for stock would be allocated among the assets underlying the stock if (a) the stock was purchased for the purpose of acquiring those assets and (b) the acquired corporation was promptly liquidated into the purchasing corporation. This rule favored the Government where the price paid was less than the cost basis of the assets acquired, and it favored the taxpayer where the price was in excess of the cost basis of the assets acquired. However, there was no certainty as to when the rule would be applied, and there was difficulty in obtaining Treasury Department approval except at higher administrative levels.

Section 334(b) (2) now provides that, if the acquiring parent corporation has purchased ${ }^{104} 80$ per cent of the stock of the subsidiary during a 12-month period, and within two years after such purchase the acquired subsidiary adopts a plan of liquidation, the property thereby distributed to the parent will have a cost basis equal to "the adjusted basis of the stock with respect to which the distribution was made."

Under prior law, given the proper factual situation, the transfer of the cost basis of the acquired stock to the underlying assets was

102. INT. Rev. CoDE of 1954, §392(b).

103. 187 F.2d 718 (5th Cir.), cert. denied, 342 U.S. 827 (1951).

104. A "purchase" is any acquisition except from a family member within the constructive ownership area defined by $\S 318(\mathrm{a})$, or from a decedent, or as the result of a tax-free exchange. INT. REv. CODE OF 1954, §334(b) (3). 
mandatory. Indeed, in the Kimbell-Diamond case the Treasury Department succeeded in forcing the purchasing company to use the lower cost of the stock as the basis of the underlying assets acquired. Under the 1954 Code the taxpayer, in a very real sense, has an election in that he may postpone liquidation of the acquired subsidiary for a period of two years and a subsequent tax-free liquidation under Section 332 will cause the subsidiary's assets to be transferred to the parent at their original cost basis in the hands of the subsidiary. ${ }^{105}$

\section{Carryover of Tax Attributes to Successor Corporations}

The 1939 Code provided that the transferee in a tax-free reorganization or liquidation inherited the transferor's cost basis, of the transferred assets. ${ }^{100}$ The Code was silent as to other carryover characteristics, and the transferee's succession to other tax attributes was left to court decision. However, the court decisions were inconsistent and, in great part, they elevated technical legalities above economic realities.

If corporate succession took the form of a statutory merger or consolidation, the majority view generally recognized that the tax attributes of the transferor would carry over to the transferee. ${ }^{107}$ But even in this seemingly clear area of merger, in which both corporations are legally continued in existence, a minority view has denied the right of carryover to the continuing and enlarged corporate unit. ${ }^{108}$ This minority view became the general rule if the reorganization transfer took a form other than that of merger or consolidation. It is little wonder, therefore, that the Senate committee concluded: ${ }^{109}$

"Present practice rests on court-made law which is uncertain and frequently contradictory. Your committee agrees that whether or not the items carryover should be based upon economic realities rather than upon such artificialities as the legal form of the reorganization."

The "economic realities" are now reflected in Section 381 which requires a carryover of tax attributes in the case of tax-free transfers pursuant to a statutory merger or consolidation, a type " $\mathrm{C}$ " stock-for-

105. The AII Fed. Income TAx Stat. §X658(g), comment, at 346 (Feb. 1954 Draft), required that in all cases the parent pick up the subsidiary's assets at the excess of cost basis (of the subsidiary stock) plus obligations assumed over the amount of money received upon liquidation of the subsidiary. In other words, the taxpayer had no such choice as is given in the 1954 Code.

106. Int. Rev. Code of 1939, §113(a) (6).

107. Stanton Brewery, Inc. v. Commissioner, 176 F.2d 573 (2d Cir. 1950); ALI Fed. Income Tax Stat. comments, at 327 (Feb. 1954 Draft).

108. California Casket Co., 19 T.C. 32 (1952); Jones v. Noble Drilling Co., 135 F.2d 721 (10th Cir. 1943).

109. Sen. Rep. No. 1622, 83đ Cong., 2d Sess. 52 (1954). 
assets reorganization, a type " $\mathrm{D}$ " divisive reorganization transfer of assets to a controlled corporation, a type " $F$ " reorganization (involving "a mere change in identity, form, or place of organization"), or a tax-free liquidation of a subsidiary into its parent corporation pursuant to Section $332 .{ }^{110}$ There is no provision for carryback; in fact, it is specifically provided that a net operating loss of a transferee for a year ending after the tax-free transfer shall not be carried back to any taxable year of the transferor. ${ }^{111}$

The itemization of nineteen tax attributes subject to carryover is set forth in Section 381(c). The principal carryovers relate to the net operating loss defined in Section 172, the capital loss carryover as defined in Section 1212, and more limited attributes such as accounting, inventory and depreciation methods. The most ambitious effort is the attempt to define the rules for carryover of earnings and profits following one of the specified tax-free transfers. ${ }^{112}$

Under Section 381(c)(2) the earned surplus or deficit of the transferor is deemed to be received by the acquiring corporation as of the date of distribution or transfer. A deficit of the transferor can be used to offset only those earnings accumulated by the acquiring corporation after the transfer, and a deficit of the acquiring corporation may not offset earnings of the transferor accumulated before the transfer. The effect of this provision is to confirm the rule in Commissioner $v$. Sansome ${ }^{113}$ that the transferee must pick up the transferor's accumulated earnings, and to partially negate the rule in Commissioner v. Phipps ${ }^{114}$ that the transferee may not offset its earnings with the transferor's deficit.

The complexity of the tax laws has created a "tax attribute" which, in normal times, would be regarded as a liability. This is the "net operating loss deduction" which may be carried over for five succeeding years. ${ }^{115}$ A corporation with no assets, but a substantial net operating loss, would have substantial value to an income-producing business which could merge into the loss corporation so that the income for the

110. Unless the liquidation is within $\$ 334$ (a) (2) and, therefore, results in a new basis for assets under the Kimbell-Diamond doctrine.

111. Int. Rev. Code of 1954, \$381 (b) (3).

112. ALI Fed. Income TaX Stat. $\$ \mathrm{X} 608$, comments, at 327 et seq. (Feb. 1954 Draft), suggested a smaller group of items to be carried over. It concluded that the problem of carryover of earnings and profits "was not susceptible of incorporation into the statute... [and that] .. . this matter were better left to Regulations or to the Courts for case by case treatment." Id. at 241 . The 1954 Code nevertheless tackles the problem in $\S 381$ (c) (2).

113. 60 F.2d 931 (2d Cir. 1932).

114. 336 U.S. 410 (1949). The Phipps rule is still present to the extent that the transferor's deficit may not offset earnings accumulated by the transferee before the transfer.

115. INT. Rev. CODE of 1954, §172. 
five succeeding years could be reduced or eliminated by the loss carryover. ${ }^{116}$ This device was first attacked by adding Section $129^{117}$ to the 1939 Code which disallowed the benefit of the deduction if "the principal purpose" of acquiring the loss corporation was "avoidance of Federal income or excess profits tax." The successor Section $269^{118}$ of the 1954 Code strengthens this provision by creating a prima facie case of avoidance if the price paid for the loss corporation is substantially disproportionate to (a) the adjusted basis of its property plus (b) the tax benefits not available otherwise than as a result of the transaction. ${ }^{119}$

But the loss corporation has also been attacked from another direction. Section 382 of the 1954 Code will disallow the net operating loss deduction in full if (a) at the end of the taxable year the stock ownership by any one or more of the ten largest stockholders has increased at least 50 per cent, (b) such increase is due to a purchase or redemption of the stock, and (c) the prior trade or business of the corporation has been discontinued. The net operating loss deduction will be disallowed in part if (a) the change in stock ownership results from a reorganization and (b) the stockholders of the loss corporation own less than 20 per cent of the acquiring corporation; ${ }^{120}$ in this case the loss carryover is reduced by a percentage equal to 100 per cent less five times the percentage of interest held by the loss corporation stockholders in the continuing corporation.

These complicated provisions governing the corporation with a net operating loss deduction illustrate why the tax laws cannot be effectively simplified. Section 172 provides a two-year carryback and five-year carryover of losses in order to align taxable profits, arbitrarily computed on an annual basis, with long term corporate profits. Moreover, when two corporations combine their activities it is only sensible that the losses of one should carry over and blend with the future earnings of the combined businesses. This is accomplished by another remedial provision, the new Section 381 (c) (1).

But these remedial provisions themselves created new opportunities for tax avoidance through the wholesale trafficking in tax benefits of loss corporations. Congress was then faced with the alternative of withdrawing the carryover benefits or enacting new provisions which

116. Alprosa Watch Corp., 11 T.C. 240 (1948).

117. Revenue Act of 1943, \$128(a), 58 STAт. 47 (1943).

118. For detailed discussion of $\$ 269$, see Rice, Internal Revenue Code, Section 269: Does the Left Hand Know What the Right is Doing?, 103 U. of PA. L. Rev., No. 5 (March 1955).

119. The suggestion for this revision can be found in ALI FED. INCOME TAX Stat. \& X661, comments, at 351 (Feb. 1954 Draft).

120. Section 382 will not apply if the transferor and acquiring corporations in the reorganization are owned substantially by. the same persons in the same proportion. 
would prevent improper use of the loss carryover. In this sense, the enactment of the preventive Sections 269 and 382 was preferable to elimination of the carryover benefits, although the necessary consequence was to add to the complexity of the tax laws.

\section{CONCLUSION}

If Subchapter C of the 1954 Revenue Code has sacrificed an element of simplicity, it has done so only to provide remedies and to prevent tax avoidance. Its basic framework is sound, and the 1954 revisions mirror the excellent research and considered conclusions of the American Law Institute. It might be expected that there would be inconsistencies, ambiguities, pitfalls and new loopholes to plague both the taxpayers and the Treasury Department, but we may also expect that the Commissioner's Regulations, court decisions, and the pending Revenue Act of 1955 (already in the making) will provide clarification where needed. 